\title{
Folate metabolism in epileptic and psychiatric patients
}

\author{
E. H. REYNOLDS, J. PREECE, AND A. L. JOHNSON \\ From the National Hospital for Nervous Diseases, Queen Square, London; the Area Laboratory, West Park \\ Hospital, Epsom, Surrey; and the Medical Research Council Neuropsychiatry Unit, Carshalton, Surrey
}

SUMMARY Serum and red cell folate levels and serum vitamin $B_{12}$ levels have been estimated in 33 normal controls; 34 epileptic outpatients, 19 of whom also suffered from psychiatric illness; 33 epileptic inpatients with psychiatric illness; and 30 non-epileptic inpatients with psychiatric illness. Significant lowering of serum folate and red cell folate levels was observed in epileptic patients with psychiatric illness, and a less significant fall in red cell folate levels was found in nonepileptic psychiatric patients. Serum folate levels less than $2.5 \mathrm{ng} / \mathrm{ml}$. were found in two controls, seven outpatient epileptics, 29 inpatients, and 10 non-epileptic patients. Red cell folate levels less than $100 \mathrm{ng} / \mathrm{ml}$. were found in two controls, nine outpatient epileptics, 23 inpatient epileptics and seven non-epileptic patients. A significant correlation was found between serum and red cel folate values in control, epileptic, and non-epileptic patients. In the epileptic patients there was significant association between low serum and red cell folate levels and the presence of psychiatric illness. The origin and possible significance of these findings are discussed.

Several studies have confirmed a high prevalence (30 to $90 \%$ ) of low serum folate levels $(<3 \mathrm{ng} / \mathrm{ml}$.) in drug-treated epileptic patients (see Chanarin, 1969; Reynolds, 1970, 1971). There is evidence of a particular association between this finding and disturbances of the mental state of various types (Reynolds, 1971), though Jensen and Olesen (1970) have concluded that low serum folate values in epilepsy are of no clinical importance.

Other studies have revealed a prevalence of low serum folate levels in up to $25 \%$ of non-epileptic psychiatric patients (Carney, 1967; Hunter, Jones, Jones, and Matthews, 1967; Ibbotson, Dilena, and Horwood, 1967; Hällström, 1969; Källström and Nylöf, 1969; Jensen and Olesen, 1969b; Reynolds, Preece, Bailey, and Coppen, 1970). The origin and significance of this finding are not yet clear.

It is recognized that red cell folate levels may be a better guide to folate status than serum values (Hoffbrand, Newcombe, and Mollin, 1966; Chanarin, 1969). We have, therefore, examined red cell folate levels in a series of normal controls, epileptic patients with and without mental illness, and nonepileptic psychiatric patients. The object of the study was to ascertain whether the previously reported changes in serum folate levels in epileptic and in psychiatric patients are accompanied by a corresponding lowering of red cell folate levels. It was not our purpose to establish the cause of low levels or to relate them to any particular type of mental illness.

\section{PATIENTS}

The following groups, of both sexes, have been studied.

GROUP A Thirty-three normal controls (mean age 32 years) mainly laboratory staff and hospital personnel.

GROUP B Thirty-four epileptic patients (mean age $35 \div$ years) attending the outpatient department of the National 3 Hospital. Nineteen of this group also manifested one or more of the following conditions: behaviour or personality disorder, affective illness, 'schizophrenialike' psychosis, or intellectual deterioration.

GROUP C Thirty-three epileptic patients (mean age 49 D years) who were either temporary or long-stay patients in one of the group of psychiatric hospitals served by $N$ the Area Laboratory at Epsom - that is, West Park, Horton, Long Grove. All these patients had psychiatric N disorders, mainly 'schizophrenia-like' psychoses, beha- స్ట 
vioural and affective disorders. In the majority, these were present against a background of intellectual deterioration.

GROUP D Thirty non-epileptic psychiatric patients(mean age 56 years) who were also either temporarily or permanently receiving treatment in the same group of psychiatric hospitals for acute or chronic schizophrenia, organic psychoses, or affective disorders.

All epileptic patients were receiving at least two, often three, of the major anticonvulsant drugs: phenobarbitone ( 90 to $180 \mathrm{mg}$ daily), diphenylhydantoin (200 to $400 \mathrm{mg}$ daily), and primidone (500 to $1500 \mathrm{mg}$ daily). A few patients were also on ethosuximide, sulthiame, phenylethylacetylurea, acetazolamide, or chlordiazepoxide.

Most of the psychiatric patients, including those with epilepsy, were receiving psychotropic drugs, usually phenothiazines or tricyclic antidepressants.

\section{METHODS}

All patients had a detailed haematological assessment, including haemoglobin, haematocrit, blood film, and in many cases sternal marrow examination.

Serum folate levels were assayed with lactobacillus casei (normal range 2.5 to $15 \mathrm{ng} / \mathrm{ml}$.), red blood cell folate by the method of Hoffbrand et al. (1966) (normal range 00 to $550 \mathrm{ng} / \mathrm{ml}$.), and vitamin $B_{12}$ using lactobacillus leichmanii (normal range 150 to $800 \mu \mu \mathrm{g} / \mathrm{ml}$.).

STATISTICS Before statistical analysis, the data were transformed logarithmically to normalize distributions. Comparisons between the groups were made by an analysis of variance (randomized block design) after testing for homogeneity by Bartlett's test. All pair-wise comparisons between means were made using the least significant difference. Where heterogeneity of variances was found by Bartlett's test the data were analysed using a modified $t$ test (Bailey, 1959) and appropriate care taken over significance levels.

\section{RESULTS}

It is relevant to note that only three patients (all in group C) were mildly anaemic (haemoglobin between
11 and $12 \mathrm{~g} / 100 \mathrm{ml}$. Otherwise all haemoglobin levels were above $12 \mathrm{~g} / 100 \mathrm{ml}$.

SERUM FOLATE LEVELS These are summarized in Table 1.

In the control group mean serum folate was $4.76 \mathrm{ng} / \mathrm{ml}$. Two controls had values less than $2.5 \mathrm{ng} / \mathrm{ml}$-that is, 2 and $1.5 \mathrm{ng} / \mathrm{ml}$. respectively.

In the outpatient epileptic group the mean serum folate was $3.96 \mathrm{ng} / \mathrm{ml}$. This was not significantly different from control values. However, those outpatients with psychiatric illness had a mean value of $3.3 \mathrm{ng} / \mathrm{ml}$. which was significantly lower than outpatients without psychiatric illness, mean $4 \cdot 8$ $\mathrm{ng} / \mathrm{ml}$. $(\mathrm{P}<0.005)$, and also significantly lower than the control group $(P<0.002)$. Seven outpatients had values less than $2.5 \mathrm{ng} / \mathrm{ml}$. and these were all in the subgroup with psychiatric illness.

The inpatient epileptics with psychiatric illness had a mean serum folate of $1.8 \mathrm{ng} / \mathrm{ml}$. $(\mathrm{P}<0.001)$. Twenty-nine of these patients had values less than $2.5 \mathrm{ng} / \mathrm{ml}$.

The non-epileptic psychiatric group had a mean serum folate of $4 \cdot 21 \mathrm{ng} / \mathrm{ml}$., which was not significantly different from controls. However, 10 of these patients $(33 \%)$ had values less than $2 \cdot 5 \mathrm{ng} / \mathrm{ml}$.

RED CELl FOLATE LEVELS These are summarized in Table 2, and Figs. 1, 2, and 3.

In the control group the mean red cell value was $187 \mathrm{ng} / \mathrm{ml}$. The two controls with subnormal serum values also had subnormal red cell values, 85 and $61 \mathrm{ng} / \mathrm{ml}$. respectively.

In the outpatient epileptic group, mean red cell folate was $136.3 \mathrm{ng} / \mathrm{ml}$. $(\mathrm{P}<0.005)$. In the subgroup with psychiatric illness mean red cell folate was $114.2 \mathrm{ng} / \mathrm{ml}$., which was significantly lower than both the subgroup without psychiatric illness, mean $164.3 \mathrm{ng} / \mathrm{ml}$. $(\mathrm{P}<0.001)$, and controls $(\mathrm{P}<0.001)$. Nine

TABLE 1

SERUM FOLATE LEVELS IN CONTROL, EPILEPTIC, AND PSYCHIATRIC PATIENTS

\begin{tabular}{|c|c|c|c|c|}
\hline & Number & $\begin{array}{c}\text { Mean } \\
(n g / m l .)\end{array}$ & $\begin{array}{l}\text { Log variate } \\
\text { Mean } \pm S E\end{array}$ & $\begin{array}{c}P \\
\text { (significance of difference } \\
\text { from controls) }\end{array}$ \\
\hline $\begin{array}{l}\text { Normal controls } \\
\text { Odtpatient epileptics }\end{array}$ & 33 & $4 \cdot 76$ & $0.646 \pm 0.029$ & \\
\hline $\begin{array}{l}\text { a. Total } \\
\text { b. Without psychiatric illness }\end{array}$ & $\begin{array}{l}34 \\
15\end{array}$ & $\begin{array}{l}3.96 \\
4 \cdot 80\end{array}$ & $\begin{array}{l}0.566 \pm 0.028 \\
0.656 \pm 0.041\end{array}$ & $\begin{array}{l}\text { NS } \\
\text { NS } \\
\quad \text { b. v c. } \\
\quad \text { P }<0.005\end{array}$ \\
\hline $\begin{array}{l}\text { c. With psychiatric illness } \\
\text { Inpatient .epileptics } \\
\text { with psychiatric illness } \\
\text { Non-epileptic patients } \\
\text { with psychiatric illness }\end{array}$ & $\begin{array}{l}33 \\
30\end{array}$ & $1 \cdot 80$ & $\begin{array}{l}0.495 \pm 0.037 \\
0.222 \pm 0.029 \\
0.511 \pm 0.057\end{array}$ & 0.002 \\
\hline
\end{tabular}


TABLE 2

RED CELL FOLATE LEVELS IN CONTROL, EPILEPTIC, AND PSYCHIATRIC PATIENTS

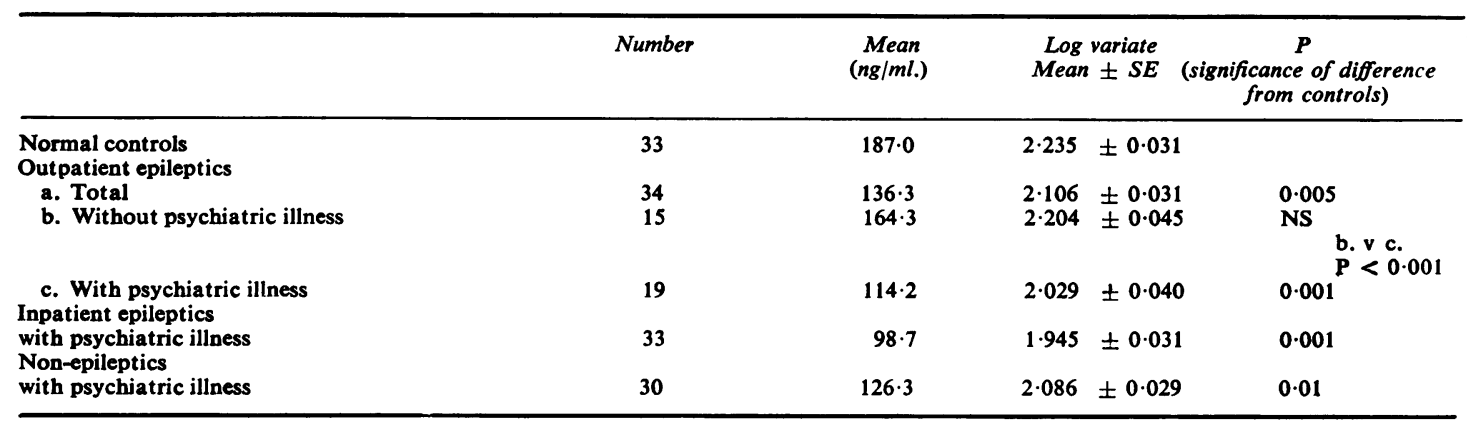

TABLE 3

VITAMIN $B_{12}$ LEVELS IN CONTROL, EPILEPTIC AND PSYCHIATRIC PATIENTS

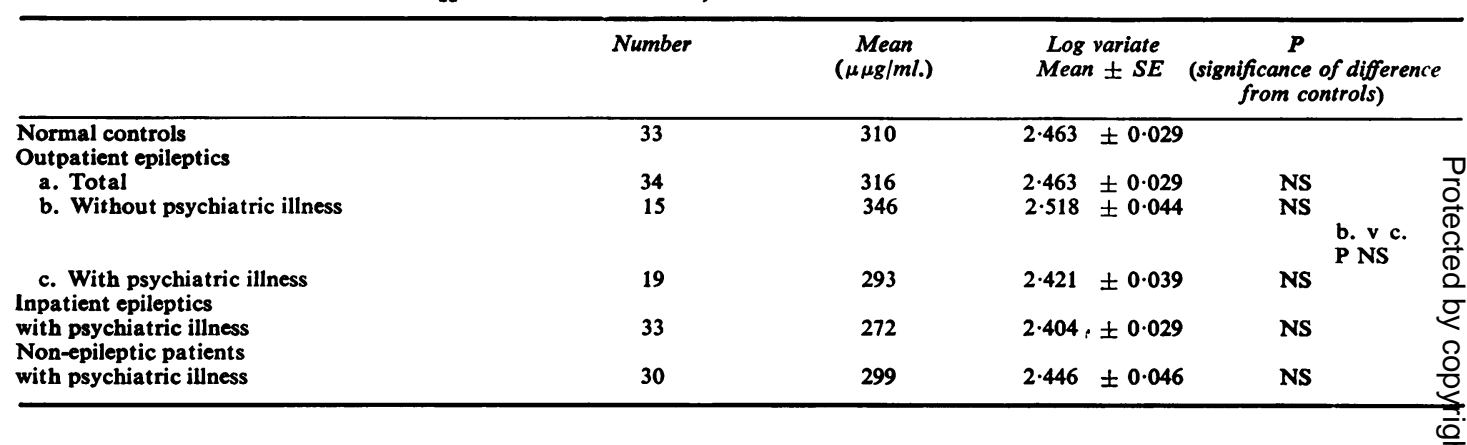

patients had values less than $100 \mathrm{ng} / \mathrm{ml}$., all in the subgroup with psychiatric illness.

The inpatient epileptics with psychiatric illness had a mean red cell folate of $98.7 \mathrm{ng} / \mathrm{ml}$. $(\mathrm{P}<0.001)$. Twenty-three patients had values less than $100 \mathrm{ng} / \mathrm{ml}$.

The non-epileptic psychiatric group had a mean red cell folate of $126.3 \mathrm{ng} / \mathrm{ml}$. $(\mathrm{P}<0.01)$. Seven patients had values less than $100 \mathrm{ng} / \mathrm{ml}$.

RELATIONSHIP BETWEEIV SERUM ANI RED CELL FOLATE LEVELS A regression for red cell on serum folate was calculated as follows:

$\begin{array}{ll}\text { Controls } & \log (\mathrm{RC} \text { Fol }) \\ & =1.82+0.64 \mathrm{Log} \text { (Ser. Fol }) \\ & \text { Correlation coefficient } \\ & 0.63(\mathrm{P}<0.001) \\ & \text { Regression coefficient }=0.64 \pm 0.14 \\ & (\mathrm{~B}+\mathrm{C} \text { combined }) \\ \text { Epileptics } & \text { Log } \mathrm{RC} \text { Folate } \\ & =1.84+0.46 \mathrm{Log} \text { (Ser. Fol }) \\ & \text { Correlation coefficient } \\ & 0.55(\mathrm{P}<0.001) \\ & \text { Regression coefficient }=0.46 \pm 0.09\end{array}$

$\begin{array}{cll}\text { Non-epileptic } & \log (\mathrm{RC} \text { Folate }) & \\ & =1.94+0.285 \mathrm{Log}(\text { Ser. Fol }) . & \\ & \text { Correlation coefficient } & \\ & 0.55(\mathrm{P}<0.001) & \\ & \text { Regression coefficient } & =0.29 \pm 0.08 .\end{array}$

The three lines were compared by analysis of $\overrightarrow{\overrightarrow{0}}$ covariance. There were no significant differences in $\exists$ either the residual deviations, the slopes, or the elevations.

SERUM VITAMIN $B_{12}$ LEVELS These are summarized in Table 3.

In the control group mean vitamin $B_{12}$ was $310 \mu \mu \mathrm{g} / \mathrm{ml}$.

In the outpatient epileptic group the mean vitamin $B_{12}$ was $316 \mu \mu \mathrm{g} / \mathrm{ml}$. (NS). In the subgroup without psychiatric illness the mean was $346 \mu \mu \mathrm{g} / \mathrm{ml}$. (NS), and in those with psychiatric illness, $293 \mu \mu \mathrm{g} / \mathrm{ml}$.

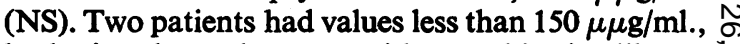
both in the subgroup with psychiatric illness. N

In the inpatient epileptic group, the mean vitamin 


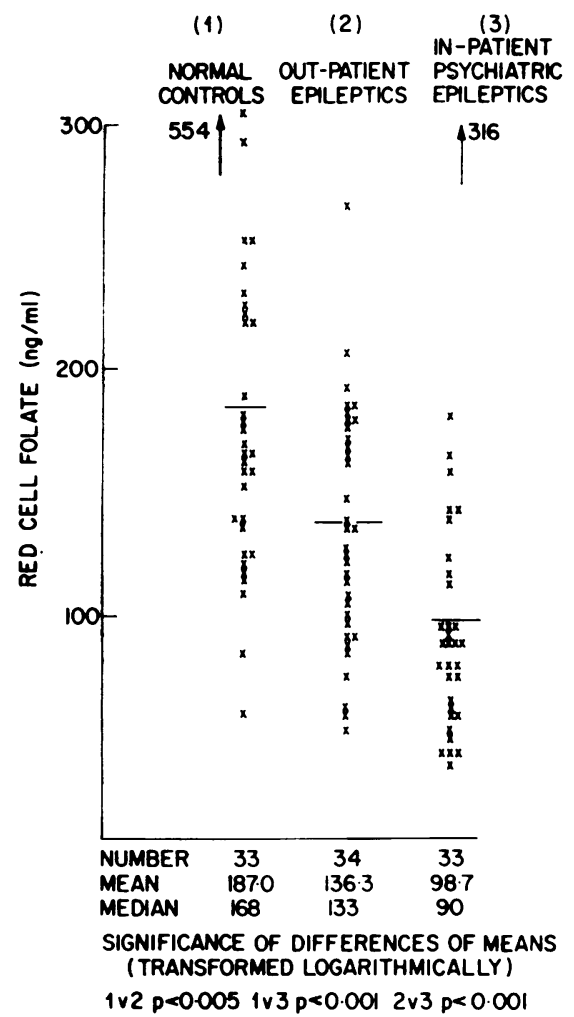

FIG. 1. Red cell folate levels in control and epileptic patients.

$\mathbf{B}_{12}$ was $272 \mu \mu \mathrm{g} / \mathrm{ml}$. (NS). Two patients had values less than $150 \mu \mu \mathrm{g} / \mathrm{ml}$.

In the non-epileptic patients, the mean vitamin $B_{12}$ was $299 \mu \mu \mathrm{g} / \mathrm{ml}$. (NS). Three patients had values less than $150 \mu \mu \mathrm{g} / \mathrm{ml}$.

\section{DISCUSSION}

Our results indicate that the subnormal serum folate levels previously reported in epileptic and psychiatric patients are also reflected in a fall in red cell folate levels in a significant proportion of patients, the correlation between serum and red cell values being 0.63 for controls, 0.55 for epileptic patients, and 0.55 for non-epileptic psychiatric patients. A similar correlation was reported by Hoffbrand, et al. (1966) in control and haematological patients.

EPILEPTIC PATIENTS The fall in red cell folate values in our epileptic patients is in agreement with the report of Dahlke and Mertens-Roesler (1967) who noted subno:mal red cell levels in all 11 epileptic children with subnormal serum folate levels. On the other hand, Jensen and Olesen (1969a) have claimed

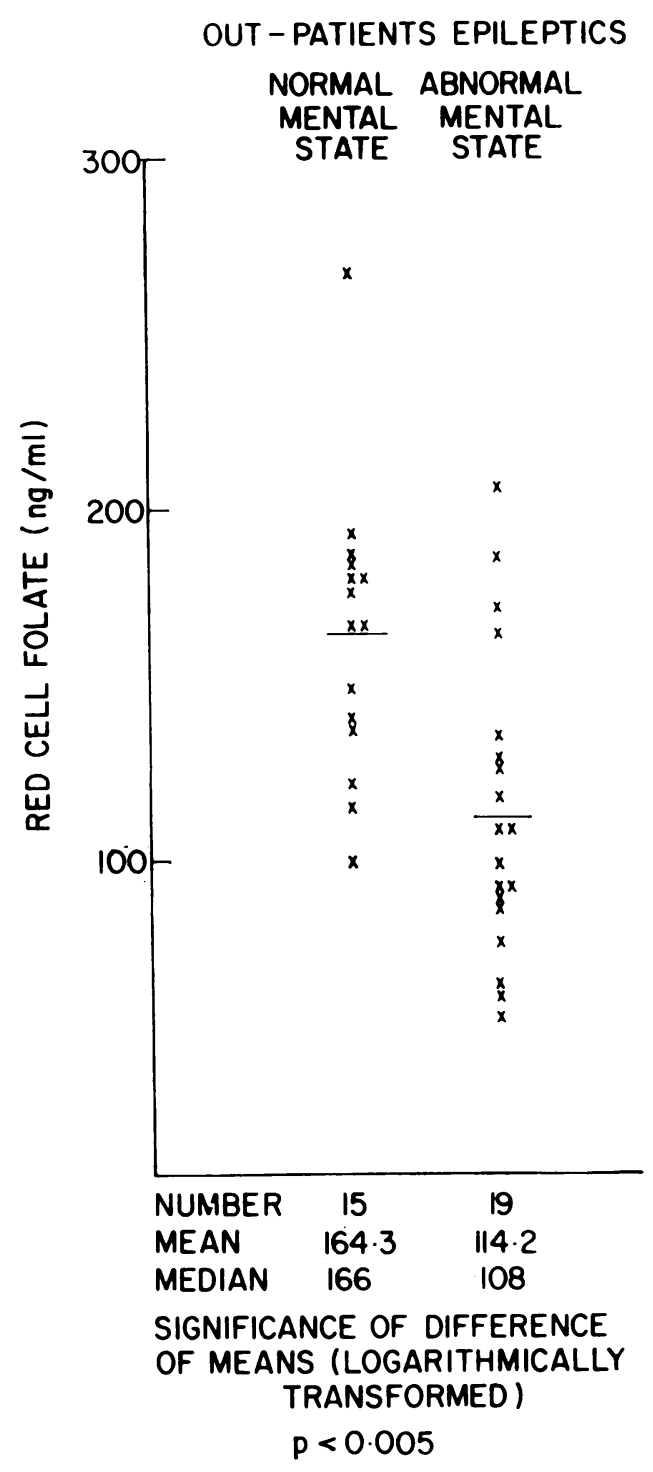

FIG. 2. Red cell folate levels in outpatient epileptic patients.

that whole blood folate levels in epileptic patients are normal. However, as they had no control group and as their mean whole blood level in epileptics was below the lower normal limit reported by other Scandinavian authors as well as below the range of values they subsequently reported in psychiatric patients (Jensen and Olesen, 1969b), their results appear to us to be abnormal and consistent with our findings (Preece, Reynolds, and Johnson, 1971). 


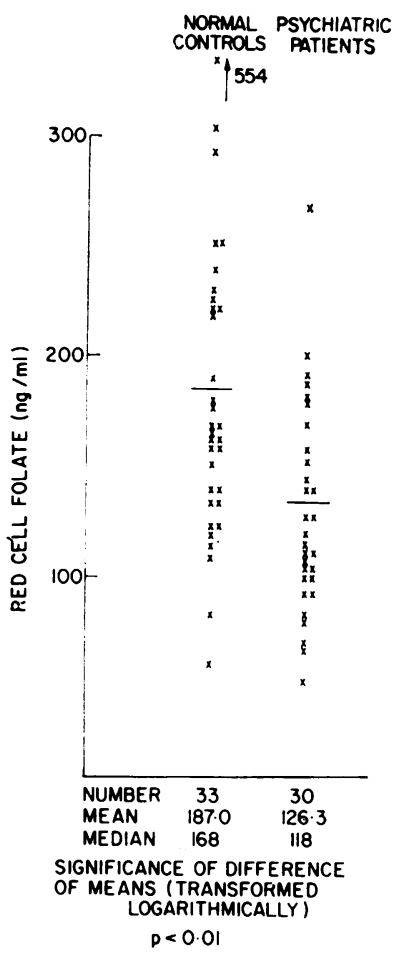

FIG. 3. Red cell folate levels in control and psychiatric patients.

In our epileptic patients the lowest red cell values were in the psychiatric inpatient group (Fig. 1) nearly all of whom had evidence of intellectual deterioration and many of whom were psychotic. That this association is not simply due to hospitalization is suggested by the fact that the outpatient epileptics with mental illness also had significantly lower values than both controls and epileptic patients with normal mental states (Fig. 2). These findings are in agreement with other evidence linking folate disturbances to mental illness in epilepsy. Reynolds, Preece, and Chanarin (1969) noted that in a hospital population serum folate levels were lower in epileptic patients with various abnormal mental states than in those with normal mental states, though this was statistically significant only in those with dementia and schizophrenia-like psychoses. In an unselected population, Snaith, Mehta, and Raby (1970) found significantly lower serum folate levels in both psychotic (schizophrenia-like, and depressive) and non-psychotic (reactive depression, aggression, and irritability) epileptics compared with epileptics without mental illness. Callaghan, Mitchell, and Cotter (1969) reported significantly lower folate levels in psychotic than non-psychotic epileptic patients. Furthermore, the highest incidence of low serum folate levels in epilepsy has been reported from a psychiatric hospital (Ibbotson et al., 1967) and in institutionalized patients with intellectual deterioration (Jensen and Olesen, 1969a). In a study of cerebrospinal fluid (CSF) folate levels in epilepsy, Reynolds et al. (1969) found significantly lower values in patients with various types of mental disturbance (schizophrenia-like psychoses, depression, behaviour-disorders) but the lowest values were in dementia. In summary, it seems that low folate levels in serum, red cells, and CSF may be significantly associated with various forms of mental illness in epilepsy, especially perhaps psychoses and dementia. This does not imply, however, that all epileptic patients with mental illness have low folate levels or that all patients who have low folate levels necessarily have mental illness.

PSYCHIATRIC PATIENTS The finding of subnormal serum folate levels in one third of our patients is $N$ consistent with the reports of Carney (1967) o Ibbotson et al. (1967), Hunter et al. (1967), HällströnP (1969), Källström and Nylof (1969) Jensen an\& Olesen (1969b), and Reynolds et al. (1970). As in the epileptic patients, our results indicate that this is accompanied by evidence of a fall in red cell values in many. This is in agreement with Hällström (1969). 윽 who reported subnormal whole blood folate levels $\overrightarrow{0}$ in six out of nine psychiatric patients with subnormal serum folate levels, but not with Jensen and Olesen (1969b) whose seven patients with low serum levels were said to have normal whole blood values, though again no control data were included.

CAUSES OF LOW FOLATE LEVELS In epileptic patients the evidence that anticonvulsant drugs are predominantly responsible for the reported changes in serum, red cell, and CSF folate levels appears convincing, though the mechanism has not been clarified (Chanarin, 1969). Woodbury and Kemp (1971) have reported that diphenylhydantoin inhibits the uptake of tritium labelled folate into various tissues of the rat, including brain and CSF. In the non-epileptic psychiatric patients the situation is less clear but has been little investigated. Carney and Sheffield (1970) suggested that psychotropic drugs (especially barbiturates, phenothiazines, and tricyclic antidepressants), dietary deficiency, physical illness, and chronicity of mental illness may all be relevant, though in $20 \%$ of their patients no such factor could be identified. On the other hand, Reynolds et al. (1970) found no clear relationship 
between low serum levels and previous barbiturate therapy or dietary history (though reliable data are difficult to obtain); and Gunderson (1969) reported that tricyclic antidepressants did not influence serum levels.

SIGNIFICANCE OF LOW FOLATE LEVELS The nature of the relationship between folate disturbances and mental illness is complex and controversial. Following their haematological study (Reynolds, Chanarin, Milner, and Matthews, 1966) and the subsequent improvement, mainly in drive, alertness, and mood, in 22 out of 26 epileptic patients treated with folic acid (together with vitamin $\mathbf{B}_{12}$ in some cases) (Reynolds, 1967a), these authors suggested a causal relationship. A similar conclusion was reached by Strachan and Henderson (1967) on the basis of two non-epileptic patients with dementia who improved on folic acid therapy; by Carney (1967), who noted a particular association between folate deficiency and organic psychoses and affective illness in his study of 423 psychiatric patients; and by Neubauer (1970) who reported an improvement in the behaviour and mental state in 19 out of 50 folate deficient epileptic children treated with folic acid and vitamin $B_{12}$. Included in the concept of a causal relationship is the possibility that folate deficiency which is secondary to mental illness-for example, for dietary reasons-many in turn aggravate the underlying psychiatric disorder (Reynolds, 1967b; Carney, 1967). Further support was the finding of an association between folate deficiency, apathy, and a poor response to antidepressant therapy in a study of 100 depressed patients by Reynolds et al. (1970); and the report of Carney and Sheffield (1970) that in a controlled but retrospective trial of the vitamin, in addition to other appropriate psychiatric therapy, significantly greater improvement occurred in patients with organic psychoses, depression, and schizophrenia.

On the other hand, on the basis of their 'normal' whole blood folate levels and a negative double blind trial of folic acid in intellectually deteriorated epileptics, Jensen and Olesen (1969a, 1970) are of the opinion that low serum folate levels are of no importance in these clinical situations. Ralston, Snaith, and Hinley (1969) also report no significant effects of folic acid on aggressive behaviour in a three month controlled trial in epileptic patients, though they point out that they had not yet repleted body stores of folate at the end of the three month period. Weckman and Lehtovaara (1969) also question any relationship between anticonvulsant drugs, folate metabolism, and psychiatric illness since they found no significant difference in CSF folate levels between epileptic patients and controls. However, these authors, alone among many, also failed to find changes in serum folate levels in epileptic patients, and furthermore their control CSF folate values are much lower than in other reported studies (see Reynolds et al., 1969).

The problem is further complicated by the fact that in epileptic patients at least the administration of folic acid results in a sharp drop in serum vitamin $\mathrm{B}_{12}$ levels (Reynolds et al., 1966; Hunter, Barnes, and Matthews, 1969; Reynolds, Wrighton, Johnson, Preece, and Chanarin, 1971), suggesting that it may be necessary to add vitamin $B_{12}$ in some patients before achieving any therapeutic effect (Reynolds, 1967a, 1970; Neubauer, 1970). Shaw et al. (1970) also noted that CSF folate levels were still rising very slowly after six months of therapy in their severely demented patients. This observation is consistent with the claims of a slow response to therapy reported by Reynolds (1967a) and Neubauer (1970).

In any consideration of a possible causal connection between low folate levels and nervous system dysfunction, it must be borne in mind that it is clearly possible for patients, both epileptic and nonepileptic, to have low folate levels in the absence of any clinical evidence of neuropsychiatric symptomatology. However, this is also true of vitamin $B_{12}$ deficiency, in which nervous system involvement may be found in only $10 \%$ of patients with Addisonian anaemia (Brain and Walton, 1969). In either vitamin deficiency state it may reasonably be postulated that other factors determine whether or not neuropsychiatric complications develop. One such factor is likely to be the duration of the deficiency. This may be an important factor in epileptic patients who receive anticonvulsant drugs for many years. In this connection it is of interest that in relatively short-term experiments in rats diphenylhydantoin was reported to reduce serum, cerebrospinal fluid, and tissue folate levels although cerebral folate activity remained within the normal range (Allen and Klipstein, 1970). Whether long-term administration of the drug would ultimately also reduce cerebral folate levels remains to be determined.

Clearly, further studies are required to resolve some of these problems and differences. They should include investigations which take into account the complex relationship between folate and vitamin $\mathbf{B}_{12}$ metabolism, and between biochemical and nonbiochemical factors (psychological, brain damage, fits) in the genesis of mental illness (Reynolds, 1968, 1971). This would appear to be worth while, not only because of the relatively high concentrations of folate in the CSF and brain, but also because folate is likely to be involved in cerebral nucleoprotein, 
indole and catecholamine, and methyl group metabolism, all of which have been incriminated in various types of mental illness. Furthermore, in the last few years three separate inborn errors of folate metabolism or transport have been described, all associated with mental retardation (Arakawa, 1970).

We are very grateful to the physicians at the National Hospitals for Nervous Diseases, West Park, Horton, and Long Grove Hospitals, for permission to study their patients; to Dr. C. J. Earl, Dr. V. Marks, Dr. D. Richter, and Dr. Denis Williams for their support and advice; and to Mrs. Crowley and Miss R. Miller for their excellent technical assistance.

\section{REFERENCES}

Allen, C. D., and Klipstein, F. A. (1970). Brain folate concentration in folate-deficient rats receiving diphenylhydantoin. Neurology (Minneap.), 20, 403.

Arakawa, T. (1970). Congenital defects in folate utilization. Amer. J. Med., 48, 594-598.

Bailey, N. T. J. (1959). Statistical Methods in Biology. English Universities Press: London.

Brain, Lord, and Walton, J. N. (1969). Brain's Diseases of the Nervous System. 7th ed. Oxford University Press: London.

Callaghan, N., Mitchell, R., and Cotter, P. (1969). The relationship of serum folic acid and vitamin $B_{12}$ levels to psychosis in epilepsy. Irish J. med. Sci. 7th series, 2, 497-505.

Carney, M. W. P. (1967). Serum folate values in 423 psychiatric patients. Brit. med. J., 4, 512-516.

Carney M. W. P., and Sheffield, B. F. (1970). Associations of subnormal serum folate and vitamin $B_{12}$ and effects of replacement therapy. J. nerv. ment. Dis., 150, 404-412.

Chanarin, I. (1969). The Megaloblastic Anaemias. Blackwell Scientific Publications: Oxford.

Dahlke, M. B., and Mertens-Roesler, E. (1967). Malabsorption of folic acid due to diphenylhydantoin. Blood, 30, 341-351.

Gunderson, H. J. G. (1969). Serum folate in psychiatric patients under long-term treatment with tricyclic neuroleptic drugs. Acta psychiat. scand., 45, 133-136.

Hällström, T. (1969). Serum $B_{12}$ and folate concentrations in mental patients. Acta psychiat. scand., 45, 19-36.

Hoffbrand, A. V., Newcombe, B. F. A., and Mollin D. L. (1966). Method of assay of red cell folate activity and the value of the assay as a test for folate deficiency. $J$. clin. Path., 19, 17-28.

Hunter, R., Jones, M., Jones, T. G., and Matthews, D. M. (1967). Serum $B_{12}$ and folate concentrations in mental patients. Brit. J. Psychiat., 113, 1291-1295.

Hunter, R., Barnes, J., and Matthews, D. M. (1969). Effect of folic-acid supplement on serum vitamin- $B_{12}$ levels in patients on anticonvulsants. Lancet, 2, 666-667.

Ibbotson, R. N., Dilena, B. A., and Horwood J. M. (1967). Studies on deficiency and absorption of folates in patients on anticonvulsant drugs. Aust. Ann. Med., 16, 144-150. Jensen, O. N., and Olesen, O. V. (1969a). Folic acid and anticonvulsive drugs. Arch. Neurol. (Chic.), 21, 208-214.

Jensen, O. N., and Olesen, O. V. (1969b). Folic acid concentrations in psychiatric patients. Acta psychiat. scand., 45, 289-294.

Jensen, O. N., and Olesen, O. V. (1970). Subnormal serum folate due to anticonvulsive therapy. Arch. Neurol. (Chic.), 22, 181-182.

Källström, B., and Nylöf, R. (1969). Vitamin B $_{12}$ and folic $\vec{\Sigma}$ acid in psychiatric disorders. Acta psychiat. scand., 45, 137-152.

Neubauer, C. (1970). Mental deterioration in epilepsy due to folate deficiency. Brit. med.J., 2, 759-761.

Preece, J., Reynolds, E. H., and Johnson, A. L. (1971). Relation of serum to red cell folate concentrations in drug $\overline{\frac{\omega}{T}}$ treated epileptic patients. Epilepsia (Amst.). (In press, December.)

Ralston, A. J., Snaith, R. P., and Hinley, J. B. (1970). ڤ Effects of folic acid on fit-frequency and behaviour in $\overrightarrow{0}$ epileptics on anticonvulsants. Lancet, 1, 867-868.

Reynolds, E. H. (1967a). Effects of folic acid on the mental state and fit-frequency of drug-treated epileptic patients. $\vec{\omega}$ Lancet, 1, 1086-1088.

Reynolds, E. H. (1967b). Vitamin $B_{12}$ and folate deficiencies. Brit. J. Psychiat., 113, 681-683.

Reynolds, E. H. (1968). Epilepsy and schizophrenia. Relation- $\omega$ ship and biochemistry. Lancet, 1, 398-401.

Reynolds, E. H. (1970). Iatrogenic disorders in epilepsy. In Modern Trends in Neurology, 5, pp. 271-286. Edited bN D. Williams. Butterworths: London.

Reynolds, E. H. (1971). Anticonvulsant drugs, folic ac雨 을 metabolism, fit-frequency and psychiatric illness. Psychia Neurol. Neurochir., 74, 167-174.

Reynolds, E. H., Chanarin, I., Milner, G., and Matthew D. M. (1966). Anticonvulsant therapy, folic acid and vitæ̧ min $\mathrm{B}_{12}$ metabolism and mental symptoms. Epileps (Amst.), 7, 261-270.

Reynolds, E. H., Preece, J. M., Bailey, J., and Coppen, (1970). Folate deficiency in depressive illness. Brit. Psychiat., 117, 287-292.

Reynolds, E. H., Preece, J., and Chanarin, I. (1969). Folic acid and anticonvulsants. Lancet, 1, 1264-1265.

Reynolds, E. H., Wrighton, R. J., Johnson, A. L., Preece, J. M., and Chanarin, I. (1971). Inter-relations of folic acid and vitamin $\mathrm{B}_{12}$ in drug treated epileptic patients. Epilepsia (Amst.) (In press.)

Shaw, D. M., MacSweeney, D. A., Johnson, A. L., O'Keefe, R., Naidoo, D., Macleod, D. M., Jog, S., Preece, J. M., and Crowley, J. M. (1971). Folate and amine metabolites $\overrightarrow{\bar{O}}$ in senile dementia: a combined trial and biochemical study. Psychol. Med., 1, 166-171.

Snaith, R. P., Mehta, S., and Raby, A. H. (1970). Serum folate and vitamin $\mathbf{B}_{12}$ in epileptiss with and without mental illness. Brit. J. Psychiat., 116, 179-183.

Strachan, R. W., and Henderson, J. G. (1967). Dementia and folate deficiency. Quart. J. Med., 36, 189-204.

Weckman, N., and Lehtovaara, R. (1969). Folic acid and anticonvulsants. Lancet, 1, 207-208.

Woodbury, D. M., and Kemp, J. W. (1971). Pharmacology oิ and mechanisms of action of diphenylhydantoin. Psychiat. Neurol. Neurochir., 74, 91-115. 